\title{
Perbedaan Resiliensi Pada Tuna Daksa Ditinjau Dari Perbedaan Usia
}

\author{
Nurul Qomariyah, dan Desi Nurwidawati \\ Program Studi Psikologi Universitas Negeri Surabaya
}

\begin{abstract}
This research was purposed to examine the differences in the resilience of people with physical impairment in term of age differences. A quantitative method used in this research. The subjects for this research were 75 people with disability who are the members of Motorcycle Indonesia motor club in the area of Surabaya and Sidoarjo, East Java, Indonesia. Data were collected using a resilience questionnaire and analyzed using mann whitney test. The result shows the significant value of 0,021 ( $p<0,05)$. This means there is a significant differences in the resilience of people with physical impairment in term of age differences. The highest resilience is shown among middle adulthood participants. It can be concluded from the result that the hypothesis of this study is accepted that "there is differences resilience among people with physical impairment in term of their age differences.
\end{abstract}

Keywords: Resilience, physical impairment, adult age

\begin{abstract}
Abstrak: Penelitian ini bertujuan untuk mengetahui perbedaan resiliensi pada tuna daksa ditinjau dari perbedaan usia. Penelitian ini menggunakan metode penelitian kuantitatif. Subjek penelitian ini adalah 75 orang anggota klub motor Disable Motorcycle Indonesia yang berada di wilayah Surabaya dan Sidoarjo. Data diperoleh dengan menggunakan skala resiliensi. Penelitian ini menggunakan analisis data uji mann whitney. Hasil uji perbedaan yang dilakukan dengan menggunakan teknik mann whitney menunjukkan nilai signifikansi $\mathrm{p}<0,05$ yakni sebesar 0,021 . Artinya terdapat perbedaan resiliensi pada tuna daksa ditinjau dari perbedaan usia. Resiliensi yang lebih tinggi pada penelitian ini ditunjukkan pada usia dewasa madya. Hasil analisis tersebut menunjukkan bahwa hipotesis "perbedaan resiliensi pada tuna daksa ditinjau dari perbedaan usia" diterima.
\end{abstract}

Kata kunci: Resiliensi, tuna daksa, usia dewasa

Menurut Somantri (2006) tuna daksa adalah suatu keadaan rusak atau terganggu sebagai akibat gangguan bentuk atau hambatan pada tulang, otot dan sendi dalam fungsinya yang normal. Penyandang tunadaksa bila dibandingkan dengan ketunaan yang lain lebih mudah dikenali karena ketunaannya tampak secara jelas dan penyandang pun menyadari hal tersebut sehingga menyebabkan mereka tidak dapat mengembangkan potensi dan kemampuannya dengan baik (Tentama, 2010). Tidak terhindarkan juga berbagai hinaan dan celaan yang sering diterima dari orangorang di sekitar yang dapat menye-babkan mereka lebih memilih untuk menarik diri dari pergaulannya. Kondisi kondisi tersebut yang membuat penyan-dang sulit untuk menerima kondisi dirinya.

Berikut data hasil Susenas (survei

Korespondensi tentang artikel ini dapat dialamatkan kepada Nurul Qomariyah melalui email: rialuki93@yahoo.com;atau ke Desi Nurwidawati melalui email: desinurwidawati@unesa.ac.id. 
sosial ekonomi nasional) tahun 2009 (Profil Penyandang Masalah Kesejahteraan Sosial, 2011) terkait penyandang tuna daksa. Jumlah penduduk penyandang tuna daksa sebesar $33,75 \%$ dari 2,13 juta jiwa dari penyandang disabilitas. Penyandang tuna daksa yang disebabkan oleh bawaan sejak lahir sebanyak 32,75\%, kecelakaan $29,04 \%$, kusta $0,91 \%$, penyakit lainnya $36,23 \%$, dan kurang gizi sebanyak $1,08 \%$.

Penyandang tunadaksa berisiko tinggi terpapar bermacam-macam sumber stres yang membuatnya digolongkan pada individu yang memiliki faktor berisiko tinggi (Benard,1991). Greenspan (dalam Kauffman \& Hallahan, 2006) mengatakan bahwa penyandang tunadaksa sangat peduli pada body image, penerimaan dari teman-temannya, kebebasan dari orang tua, penerimaan diri sendiri dan pencapaian prestasi. Penyandang tunadaksa tidak jarang mengalami gangguan psikologis terkait perasaan tidak berguna, tidak mampu, malu, minder, kecemasan dan permasalahan psikologis lainnya (Misbach, 2012). Hal tersebut juga terkait dengan penelitian yang dilakukan oleh AlrikssonSchmidt dkk (2007), bahwa penyandang tuna daksa mengalami risiko penurunan kualitas hidup. Berdasarkan hasil penelitian tersebut, peneliti menyimpulkan bahwa kualitas hidup penyandang tuna daksa dapat ditingkatkan dengan membangun resiliensi di dalam dirinya. Penyandang tuna daksa dapat menjadi individu yang resilien. Individu dapat dikatakan resilien jika dapat bangkit dari masalah disabilitas fisiknya. Orang yang resilien tahu bagaimana ia harus menghadapi suatu masalah dan dapat menemukan cara penyelesaiannya. Mereka tetap berkembang meskipun lingkungan berubah terus menerus, karena mereka fleksibel, cerdas, kreatif, cepat beradaptasi serta mau belajar dari pengalaman (Sudaryono, 2007). Hal tersebut dilatarbelakangi oleh adanya optimisme untuk dapat melanjutkan kehidupan sehari-hari dari segi pendidikan, pekerjaan, aksesi- bilitas, informasi teknologi, untuk mencapai kemandirian, kesetaraan dan kesejahteraan penyandang tunadaksa. Desmita (2012) menyampaikan bahwa resiliensi dapat dipahami sebagai kemampuan atau kapasitas yang dimiliki seseorang yang memungkinkannya untuk menghadapi, mencegah, meminimalkan dan bahkan menghilangkan dampakdampak yang merugikan dari kondisi yang tidak menyenangkan bahkan mengubah kondisi kehidupan yang menyengsarakan menjadi suatu hal yang wajar untuk diatasi.

Individu harus bangkit dari situasi sulit dalam kehidupannya dan menerima keadaan dirinya. Keadaan ini disebut kemampuan resiliensi, yaitu kapasitas individu untuk mengatasi dan meningkatkan diri dari keterpurukan dengan merespon secara sehat dan produktif untuk memperbaiki diri sehingga mampu menghadapi dan mengatasi tekanan hidup sehari-hari (Reivich dan Shatte, 2002). Penyandang tuna daksa untuk menjadi pribadi yang resilien bukanlah hal mudah, dibutuhkan proses yang melibatkan berbagai faktor yang berperan dalam membentuk pribadi yag resilien. Reivich dan Shatte (2002) mengatakan bahwa untuk dapat menjadi individu yang resilien harus memiliki tujuh faktor yang berperan. Tujuh faktor tersebut adalah regulasi emosi, pengendalian impuls, optimisme, analisis kasual, empati, efikasi diri, serta reaching out. Kekuatan yang dimiliki individu pada setiap faktor berbeda - beda.

Resiliensi setiap individu berbeda karena tiap individu mempunyai kemampuan untuk bangkit dan mengatasi berbagai perubahan hidup yang berbeda. Menurut Grotberg (2000), kualitas resiliensi setiap orang tidaklah sama, sebab kualitas resiliensi seseorang sangat ditentukan oleh tingkat usia, taraf perkembangan, intensitas seseorang dalam menghadapi situasisituasi yang tidak menyenangkan, serta seberapa besar dukungan sosial dalam pembentukan resiliensi seseorang. 
Penyandang tunadaksa diharapkan mampu melakukan segala sesuatu demi masa depan. Bobey (dalam Anggraeni, 2008) bahwa setiap orang memiliki kapasitas resiliensi dalam dirinya. Resiliensi dapat terlihat dengan jelas apabila seseorang berada pada tantanga atau masalah. Banyaknya tantangan atau masalah yang dihadapi seseorang, maka akan semakin terlihat apakah ia telah berhasil mengembangkan karakteristik resiliensi dalam dirinya atau tidak.

Hal ini terkait pula dengan perkembangan usia tuna daksa di mana usia semakin bertambah maka memiliki peran dan tanggung jawab yang semakin besar. Ia tak lagi harus bergantung secara ekonomi, sosiologis maupun psikologis pada orang tuanya (Dariyo, 2008). Hal ini serupa dengan pernyataan yang dikemukakan Parton dan Wattam (dalam Sisca \& M, Clara, 2008) bahwa resiliensi dapat terjadi pada masa dewasa di mana seseorang memiliki banyak kesempatan, sumbersumber, dan perubahan-perubahan sosial. Resiliensi sendiri menggambarkan kualitas kepribadian manusia, yang akan selalu mengalami perubahan dan perkembangan. Sejalan dengan bertambahnya usia, maka terbuka juga kemungkinan berkembangnya resiliensi individu (Sulistyaningsih, 2009).

\section{Metode}

Jenis penelitian dalam penelitian ini adalah penelitian kuantitatif, karena penelitian ini disajikan dengan angka-angka. Hal ini sesuai dengan pendapat (Arikunto, 2006) yang mengemukakan penelitian kuantitatif adalah pendekatan penelitian yang banyak dituntut menggunakan angka, mulai dari pengumpulan data, penafsiran terhadap data tersebut, serta penampilan hasilnya. Subjek dalam penelitian ini berjumlah 75 orang anggota klub motor Disable Motorcycle Indonesia wilayah Surabaya dan Sidoarjo.
Instrument penelitian yang digunakan adalah skala resiliensi dengan menggunakan model skala likert. Skala psikologis tersebut disebar pada subjek penelitian yaitu klub motor Disable Motorcycle Indonesia wilayah Surabaya dan Sidoarjo.

Penelitian ini menggunakan teknik analisis data mann whitney yang merupakan bagian dari statistik non parametrik yang bertujuan untuk membantu peneliti di dalam membedakan hasil kinerja kelompok yang terdapat dalam sampel ke dalam dua kelompok dengan dua kriteria yang berbeda (Sujarweni, 2007). Sebelum dilakukan analisis, dilakukan uji persyaratan analisis terlebih dahulu yang meliputi: uji normalitas dan uji hipotesis. Teknik analisis dilakukan dengan bantuan program SPSS versi 21.0 for windows.

\section{Hasil dan Pembahasan}

Hasil penelitian menunjukkan bahwa terdapat perbedaan resiliensi pada tuna daksa ditinjau berdasarkan usia. Kesimpulan ini diperoleh dari hasil uji mann whitney yang menunjukkan bahwa $\mathrm{p}<0,05$, yaitu sebesar $\mathrm{p}=0,021$. Hasil tersebut menunjukkan bahwa subjek dewasa madya memiliki resiliensi yang lebih tinggi dibandingkan dewasa muda.

Menurut Grotberg (2000) kualitas resiliensi seseorang sangat ditentukan oleh tingkat usia, taraf perkembangan, intensitas seseorang dalam menghadapi situasisituasi yang tidak menyenangkan, serta seberapa besar dukungan sosial dalam pembentukan resiliensi seseorang. Pernyataan tersebut menjadi suatu rujukan bahwa tingkat usia memiliki keterkaitan dengan resiliensi seseorang. Terdapat pernyataan yang disampaikan Hurlock ( 1968) bahwa secara psikologis, dewasa muda cukup banyak yang kurang mampu mencapai kematangan akibat banyaknya masalah dihadapi dan tidak mampu diatasi dengan baik sebelum maupun setelah menikah, misalnya mencari pekerjaan, jodoh, belum 
siap menikah, masalah anak, keharmonisan keluarga. Pernyataan tersebut dapat diartikan bahwa perbedaan usia juga berpengaruh pada keadaan psikologis individu yang mana berdampak pula pada resiliensinya.

Dewasa muda merupakan usia banyak masalah. Jika seseorang tidak siap memasuki tahap ini, dia akan kesulitan dalam menyelesaikan tahap perkembangannya. Persoalan yang dihadapi seperti persoalan pekerjaan atau jabatan, persoalan teman hidup maupun persoalan keuangan, semuanya memer-lukan penyesuaian di dalamnya (Mappiare, 1983). Hal ini memungkinkan menjadi sebab individu pada dewasa muda memiliki resiliensi yang rendah. Individu ditantang untuk mulai mengatur hidup dan bertanggung jawab dengan kehidupannya. Pria mulai membentuk bidang pekerjaan dalam jenjang karir dan kepala rumah tangga, begitu pula wanita menata jenjang karirnya maupun menerima tanggung jawab sebagai ibu rumah tangga. Pada banyak aspek, individu pada dewasa muda pada taraf memulai atau menjajaki sehingga kuantitas belum terlalu banyak dan kualitasnya tidak terlalu baik. Keadaan tersebut tentu menyita energi dan waktu lebih untuk dapat fokus dalam penye-suaian. Hal tersebut sesuai dengan tugas perkembangan dewasa muda yang dikemu-kakan oleh Hurlock (1980) yaitu mulai bekerja, memilih pasangan, mengelola rumah tangga, dan mengambil tanggung jawab. Inti dari tugas perkembangan tersebut yaitu bahwa dewasa muda merupakan suatu masa penyesuaian diri dengan cara hidup baru dan memanfaatkan kebebasan yang diperolehnya (Hurlock, 2004).

Dewasa madya merupakan masa puncak dan cenderung lebih stabil. Danieli (1996) menyatakan bahwa individu dewasa madya cenderung berhasil mengatasi peristiwa yang menekan daripada kelompok individu yang lebih muda ataupun kelompok usia yang lebih tua. Tugas perkembangan dewasa madya menurut
Hurlock (1980) diantaranya yaitu tugastugas yang berkaitan dengan kehidupan keluarga serta tugas-tugas yang berkaitan dengan kejujuran. Pada dewasa madya individu memiliki peran dan tanggung jawab yang lebih besar diantaranya menjala-nkan rumah tangga, departemen, atau perusahaan, memiliki anak dan mungkin memelihara orang tua dan memulai karir baru. Tugas-tugas yang berkaitan dengan kejujuran yaitu individu dapat dilihat dari cara individu menyelesaikan masalah.

Dewasa madya dalam menyelesaikan masalah dilakukan dengan cara menganalisis permasalahan kemudian mencari beberapa alternatif pemecahan masalah dan membuat strategi untuk menyelesaikan masalah. Ketika mendekati masalah, mereka dapat berpikir logis dan melakukan adaptasi secara pragmatis terhadap kenyataan. Dengan kemampuan ini individu dewasa cenderung lebih mampu untuk mengembangkan cara-cara yang efektif dalam mengatasi peristiwa yang menekan. Hal ini juga sesuai dengan pendapat Gisela (dalam Desmita, 2006), menyatakan bahwa pemikiran dewasa madya menunjukkan suatu perubahan yang signifikan, ia percaya bahwa masyarakat yang kompleks memiliki pertimbanganpertimbangan yang praktis dan bahkan mengubah bentuk logika kaum idealis. Warner Schaie (dalam Papalia \& Feldman, 2009) menyatakan bahwa pada tahap perkembangan kognitif, dewasa madya akan mencapai puncak karir sehingga ia memiliki pekerjaan, peran, dan tanggung jawab yang lebih besar dalam sistem organisasi.

Reivich \& Shatte (2002) memaparkan tujuh faktor resiliensi yaitu regulasi emosi, impulse control, optimisme, causal analysis, empati, efikasi diri, dan reaching out. Resiliensi dipengaruhi oleh faktor internal yang meliputi kemampuan kognitif, dari tujuh faktor tersebut yang dapat mempengaruhi kemampuan kognitif pada dewasa madya 
yaitu causal analysis. Individu yang resilien adalah individu yang memiliki fleksibilitas kognitif. Causal analysis pada Dewasa madya dapat diketahui melalui kemampuannya dalam mengidentifikasikan semua penyebab yang menyebabkan kemalangan yang menimpa, tanpa memfokuskan dan memegang kendali penuh pada pemecahan masalah, dengan perlahan mulai mengatasi permasalahan yang ada, mengarahkan hidup, bangkit dan meraih kesuksesan (Reivich \& Shatte, 2002). Sehingga, dewasa madya memiliki taraf kognitif yang terus berkembang lebih baik yang berdampak pada resiliensi yang lebih tinggi pada individu.

Kematangan dan kestabilan psikologis maupun kognitif berdampak pada disabilitas fisik yang dialami oleh individu. Kematangan dan kestabilan dalam psikologis maupun kognitif lebih mungkin terjadi pada individu dewasa madya dibandingkan dewasa muda. Dewasa madya akan lebih mampu mengatasi masalah dan keadaan yang di-alaminya termasuk pula terkait disabilitas yang dialaminya. Meskipun mengalami disabilitas fisik, subjek dapat menghayati makna kehidupan tentang fisik, pekerjaan, pasangan yang sebenarnya bersifat subjektif yang mana hal tersebut memun-culkan optimisme yang berkaitan dengan resiliensi. Hal tersebut menjadikan individu mampu melanjutkan kehidupan sehari-hari meskipun lingkungan berubah terus menerus, namun mereka fleksibel, cerdas, kreatif, cepat beradaptasi serta mau belajar dari pengalaman (Sudaryono, 2007).

Selaras dengan penelitian yang dilakukan oleh Lokesh Gupta dan Rajbir Singh dengan judul Impact of Family Type on Resilience. Tujuan utama dari penelitian ini adalah untuk menguji hubungan antara jenis keluarga dan membangun resiliensi pada diri seseorang. Hasil menunjukkan bahwa orang dewasa madya memiliki resiliensi yang lebih baik yaitu 147,68 dibandingkan dewasa muda yaitu 140,62 hal itu berarti usia memainkan peran penting dalam pengembangan resiliensi. Sehingga, selaras kiranya penelitian menunjukkan bahwa resiliensi yang lebih baik ditunjukkan pada individu pada dewasa madya dibandingkan dewasa muda.

\section{Simpulan}

Berdasarkan hasil penelitian dapat disimpulkan bahwa ada perbedaan tingkat resiliensi pada tuna daksa ditinjau dari usia Hal tersebut menunjukkan bahwa hipotesis yang diajukan dalam penelitian ini diterima dengan nilai signifikansi pada penelitian ini sebesar 0,021 yang berarti $\mathrm{p}<0,05$. Hasil tersebut memiliki arti bahwa dewasa madya memiliki resiliensi yang lebih tinggi dibandingkan dewasa muda.

\section{Daftar Pustaka}

Anggraeni, R. (2008). Resiliensi Pada Penyandang Tuna Daksa Pasca Kecelakaan. (Online). http://www.gunadarma.ac.id. Diakses pada tanggal 7 Oktober 2015

Arikunto, S. (2006). Prosedur Penelitian: Suatu pendekatan Praktik. Jakarta: Rineka Cipta.
Alriksson-Schmidt, Ann I, dkk. (2007). Quality of Life and Resilience in Adolescents with a Mobility Disability. http://jpepsy.oxfordjour nals.org. Diakses pada tanggal 13 Oktober 2015.

Benard, B. (1991). Fostering Resiliency in Kids: Protective Factors in the Family, School, and Community. San Fancisco : Far West 
Laboratory for Educational Research and Bungin.

Danieli,Y. (1996). International Responses to Traumatic Stress. New York: Baywood Publishing Company,Inc.

Dariyo, A. (2008). Psikologi Perkembangan Dewasa Muda. Jakarta: Grasindo.

Desmita. (2010). Psikologi Perkembangan Peserta Didik. Bandung: PT. Remaja Rosdakarya.

Grotberg. (2000). Resilience for today : Gaining strength from adversity. Canada : Greenwood Publishing Group, Inc.

Gupta, L., Rajbir, S. (2011).Impact of Family Type on Resilience. (Online).https://www.researchgate. net. Diakses pada tanggal 24 februari 2017.

Hallahan, D. P. \& Kauffman, J. M. (2006). Exceptional learners: An introduction to special education. $10^{\text {th }}$ edition. Boston: Pearson.

Hurlock, E. B. (1968). Developmental Psychology. $5^{\text {th }}$ edition. New York : McGraw-Hill.

Mappiare, A. (1983). Psikologi Orang Dewasa. Surabaya: Usaha Nasional.

Misbach. (2012). Seluk Beluk Tunadaksa dan Strategi Pembelajarannya. Jogjakarta: Javalitera.

Nuryetty, M. T. (2011). Profil Penyandang Masalah Kesejahteraan Sosial. (Online).https://www.kemsos.go.id. Diakses pada tanggal 8 Oktober 2015.
Papalia. (2009). Human Development. $10^{\text {th }}$ edition. New York : McGrawHill

Reivich, K \& Shatte, A. (2002). The Resilience Factor : 7 Skills For Overcoming Life's inevitable obstacles. New York : Random House,Inc.

Sisca, H \& Clara, M. (2008). Resiliensi Perempuan Dewasa Muda yang Pernah Mengalami Kekerasan Seksual di Masa Kanakkanak. Jurnal Psikologi, 2(1). http://ejournal.gunadarma.ac.id.

Diakses pada tanggal 30 April 2015.

Somantri, S. (2006). Psikologi Anak Khusus. Jakarta: PT. Refika Aditama.

Sudaryono. (2007). Resiliensi dan Locus of Control Guru dan Staf Sekolah Pasca Gempa. Jurnal Psikologi Perkembangan.

(Online).http://jurnal.pdii.lipi.go.id. Diakses pada tanggal 8 April 2015.

Sulistyaningsih, W. (2009). Pengaruh pelatihan resiliensi dan penyuluhan untuk menurunkan trauma psikologis dan meningkatkan empati pada uru di kabupaten aceh selatan. Disertasi tidak dipublikasikan. Yogjakarta: Fakultas Psikologi Universitas Gadjah Mada.

Tentama, F. (2010). Berpikir Positif dan Penerimaan Diri pada Remaja Penyandang Cacat Tubuh Akibat Kecelakaan. (Online). http://download.portalgaruda.org. Diakses pada tanggal 7 Mei 2015. 